\title{
INFLUENCE OF DIFFERENT MELIORATION LOADS ON THE PHYSICO-CHEMICAL PROPERTIES OF DARK-CHESTNUT IRRIGATED SOIL
}

\section{Bidnyna I. O.}

\section{INTRODUCTION}

Modern agriculture needs measures directed to the increase of the level of crops productivity, obtaining high-quality yield with reduced expenditures for their cultivation. The reduction of expenditures for production of agricultural products can be achieved at the minimization of basic tillage at the expense of decrease in its depth, multiplicity of aggregates' passages or switching from moldboard tillage to less expensive plowless one. Besides, an important role in obtaining high and sustainable yields of crops plays the application of mineral fertilizers. By optimizing the doses of fertilizers' application, the efficiency of their use increases, expenditures and chemical load on the soil decrease. The introduction of the above-mentioned measures significantly reduces the energy, labor and material expenditures on the production at the irrigated lands.

Irrigation is one of the most powerful factors of the intensification of agricultural production. It has got wide distribution throughout the world. Nowadays, more than 270 million ha on the planet are irrigated, which is $18 \%$ of the total area of arable land, which produce $40 \%$ of the volume of agricultural products, that is the productivity of one irrigated hectare is more than twice higher than the productivity of unirrigated one. Irrigated lands in Ukraine are mainly located in the Steppe and Forest-Steppe natural and climatic zones, the total area of which is about 2 million ha, the actually irrigated every year area is 0.5-0.7 million ha ${ }^{1}$.

However, irrigation, along with a positive effect, can firstly result in the transformation of water and gas regimes, and then lead to

${ }^{1}$ Ромащенко М. І., Балюк С. А. Зрошення земель в Україні. Стан та шляхи поліпшення. Київ: Світ, 2000. 114 с. 
significant changes in the content of absorbed cations of the soil absorption complex and in a number of physical parameters. The intensity of soil transformation is especially increased with the use of water, which is limited suitable and unsuitable by the agronomical and ecological criteria ${ }^{2}$.

Therefore, this problem requires a detailed and deep experimental study of the impact of such technologies not only on the productivity of crops, but also on the soil-forming processes and ecological stability of the functioning of agroecosystems in the zone of irrigation.

The system of basic tillage, together with fertilization system, significantly determines the level of energy-saving of a technology, its ecological and economic orientation ${ }^{3}$.

The development and application of this or that soil tillage is closely connected with general changes in the industry, the nature of land use, the appropriate structure of cultivated areas, the trends in climate change and meliorative measures. Today, soil-protective resource-saving technologies of soil tillage are getting wider distribution and introduction, which allow to reduce resources and reduce the negative effect on the environment, including the fertility of soils ${ }^{4}$.

The increase in the cost of fuels, lubricants and mineral fertilizers has led to a significant increase of their share in the cost of production, so, an important value is assigned to the introduction of energy and resourcesaving technologies, which would provide the increase in yields and economical use of material resources, would be environmentally friendly and adapted to the conditions of the soil and climatic zone.

The results of perennial researches testify that the use of conventional soil tillage system with moldboard plowing is not always justified. It does not provide reliable soil protection against deflation and irrigational erosion, may lead to the over-compaction of the soil ${ }^{5}$.

2 Балюк С. А., Ромащенко М. I., Старшук В. А. Комплекс протидеградаційних заходів на зрошуваних землях України. Київ: Аграрна наука, 2013. $160 \mathrm{c}$.

3 Вожегова Р. А. та ін. Землі Інгулецької зрошувальної системи: стан та ефективне використання. Київ: Аграр. наука, 2010. 352 с.

4 Зубець М. В. та ін. Наукові основи агропромислового виробництва в зоні Степу України. К.: Аграрна наука, 2010. 986 с.

${ }^{5}$ Коваленко П. І. та ін. Землеробство в умовах недостатнього зволоження. Київ: Аграрна наука, 2000. 80 с. 
In the conditions of irrigation with the waters of the increased mineralization at the existing agricultural technologies of crops cultivation, the issue of the prolongation of the factors through the integrated interaction between crop rotation, tillage and doses of mineral fertilizers is relevant. An important value has more detailed description of these components, comparison of their impact on soil fertility rates and crop yields ${ }^{6}$.

Long-lasted studies found out that the improvement of soil fertility in the conditions of irrigation is observed at the differentiated by the depth plowless tillage, which reduces the expenditures and prevents the development of degradation soil processes. It is also established that deep plowing provides less optimal nutrition regime of soil at the beginning of crops vegetation in comparison to plowless tillage, herewith the microbiological activity of the upper layer is disturbed, the decomposition of post-harvest residues slows down and it delays the growth and development of plants ${ }^{7}$.

To determine the changes in the physical and chemical properties of the irrigated soil at different melioration loads in the zone of Ingulets irrigation system, the studies were carried out on the experimental fields of the Institute of Irrigated Agriculture of NAAS in the Department of Irrigated Agriculture during 2016-2018. Th soil of the experimental fields - dark-chestnut middle-loamy slightly alkaline, typical for Southern Steppe. The experiment was performed to study the systems of basic soil tillage and doses of fertilizers in the irrigated fruit-changing crop rotation (Table 1).

The area under the research was 2 ha, the area of the sowing was $218 \mathrm{~m}^{2}$, the estimated area was $36 \mathrm{~m}^{2}$.

The field experiences were set and conducted in accordance with the general field research methodologies ${ }^{8}$, as well as State standards.

6 Малярчук М. П., Марковська О. Є., Лопата Н. П. Продуктивність кукурудзи за різних способів основного обробітку грунту та доз внесення добрив в сівозміні на зрошенні півдня України. Зрошуване землеробство: міжвідом. темат. наук. зб. 2017. Вип. 67. С. 47-51.

${ }^{7}$ Сайко В. Ф., Малієнко А. М. Системи обробітку грунту в Україні. Київ: EKMO, 2007. 44 c.

${ }^{8}$ Вожегової Р. А. та ін. Методика польових і лабораторних досліджень на зрошуваних землях: навч. посіб. Херсон: Грінь Д.С., 2014. 286 с. 
Table 1

The scheme of the stationary experiment on the studying of basic soil tillage systems in the irrigated crop rotation

\begin{tabular}{|c|c|c|c|c|c|}
\hline \multirow{2}{*}{$\begin{array}{c}\text { No. } \\
\text { var. }\end{array}$} & \multirow{2}{*}{$\begin{array}{c}\text { Basic soil } \\
\text { tillage } \\
\text { system }\end{array}$} & \multicolumn{4}{|c|}{ Tillage under the culture crop rotation } \\
\cline { 3 - 6 } & Grain corn & Sorghum & $\begin{array}{c}\text { Winter } \\
\text { wheat }\end{array}$ & Soybean \\
\hline 1 & Plowing & $20-22(\mathrm{p})$ & $23-25(\mathrm{p})$ & $14-16(\mathrm{p})$ & $25-27(\mathrm{p})$ \\
\hline 2 & Plowless & $20-22(\mathrm{ch})$ & $23-25(\mathrm{ch})$ & $14-16(\mathrm{ch})$ & $25-27(\mathrm{ch})$ \\
\hline 3 & Plowless & $12-14(\mathrm{~d})$ & $12-14(\mathrm{~d})$ & $12-14(\mathrm{~d})$ & $12-14(\mathrm{~d})$ \\
\hline 4 & Differentiated-1 & $8-10(\mathrm{~d})$ & $\begin{array}{c}12-14(\mathrm{ch})+ \\
+38-40(\mathrm{~s})\end{array}$ & $8-10(\mathrm{~d})$ & $14-16(\mathrm{~d})$ \\
\hline 5 & Differentiated-2 & $18-20(\mathrm{p})$ & $16-18(\mathrm{ch})$ & $10-12(\mathrm{~d})$ & $14-16(\mathrm{~d})$ \\
\hline
\end{tabular}

Note: $\mathrm{p}$ - plowing; ch - chisel loosening; $\mathrm{d}$ - disc tillage; $\mathrm{s}$ - slotting.

The analysis of ion-salt composition of water extraction of the soil was determined according to the Hedroits method (GOST 26424-85); exchangeable sodium - in the extract of $1 \%$ acetic acid ammonium, flame-photometric by the GOST 2685086; exchangeable calcium and magnesium - by the DSTU 26487-85.

\section{Ion-salt composition of the irrigation water and its irrigation evaluation}

Evaluation of irrigation water quality is one of the most relevant issues of meliorative soil science and irrigated agriculture both in Ukraine and abroad. According to the Hydrogeological and Meliorative Service (HGMS) of the State Agency of Ukraine, 70-75\% of the irrigated lands' areas use water with the mineralization of less than $1 \mathrm{~g} / \mathrm{dm}^{3}$, the rest - more than $1 \mathrm{~g} / \mathrm{dm}^{3}$. At the same time the irrigation water with the mineralization of $1-2 \mathrm{~g} / \mathrm{dm}^{3}$ is used for watering of $18-20 \%$ of the area of irrigated land, and only 7-9\% of their area are irrigated with the waters with mineralization of more than $2 \mathrm{~g} / \mathrm{dm}^{3}$.

In the fresh waters, the salt composition is mainly represented by hydro carbonates of calcium and magnesium $-50-60 \%$, the rest are. In 
the mineralized waters, the sulphates and chlorides of sodium and magnesium prevail. Total mineralization and chemical composition of irrigation waters are characterized by clearly identified seasonal variability. The changes in the alkaline properties of water are noticeable, when the hydrogen power $(\mathrm{pH})$ fluctuates between 7.4-7.9 to 8.0-9.0, and sometimes higher, and the content of $\mathrm{CO}_{3}{ }^{2-}$ (soda) from the slight marks to $0.3-0.8 \mathrm{meq} / \mathrm{dm}^{3}$.

Agronomic criteria for water suitability for irrigation are defined by the DSTU $2730: 2015^{9}$, according to which the ranking of irrigation water is carried out considering the composition and properties of soils. During the evaluation of the quality of irrigation water, three classes of its suitability are distinguished: class I - Suitable, class II Limited suitable, class III - Unsuitable.

At the time of the researches conduction at the Institute of Irrigated Agriculture of NAAS, the monitoring of the chemical composition of irrigation water during the plants vegetation was carried out. In 2016, the mineralization of irrigation water fluctuated within $1.444-1.813 \mathrm{~g} / \mathrm{dm}^{3}$, in $2017-1.130-1.584 \mathrm{~g} / \mathrm{dm}^{3}$, in $2018-$ $1.418-1.891 \mathrm{~g} / \mathrm{dm}^{3}$ (Table 2 ).

The ion-salt composition of the irrigation water during the irrigation period was stable. Mineralization of the irrigation water for 2016 year averaged to $1.596 \mathrm{~g} / \mathrm{dm}^{3}$, for 2017 year $-1.432 \mathrm{~g} / \mathrm{dm}^{3}$, for 2018 year $-1.6932 \mathrm{~g} / \mathrm{dm}^{3}$. According to the chemical composition, the water belonged by the anionic composition to chloride-sulphate, and by the cation composition to magnesium-sodium.

The content of toxic salts in chloric equivalent, which characterizes the quality of water by the threat of secondary soil alkalination, is, on average, for 2016 year - $15.46 \mathrm{meq} / \mathrm{dm}^{3}$, for 2017 year - $11.48 \mathrm{meq} / \mathrm{dm}^{3}$, for 2018 year $-13.36 \mathrm{meq} / \mathrm{dm}^{3}$ and belongs to the II class (limited suitable for irrigation) (Table 3).

9 Захист довкілля. Якість природної води для зрошення. Агрономічні критерії: ДСТУ 2730:2015. К.: Держстандарт України, 2015. 13 с. (Національний стандарт України). 
$\frac{N}{0}$

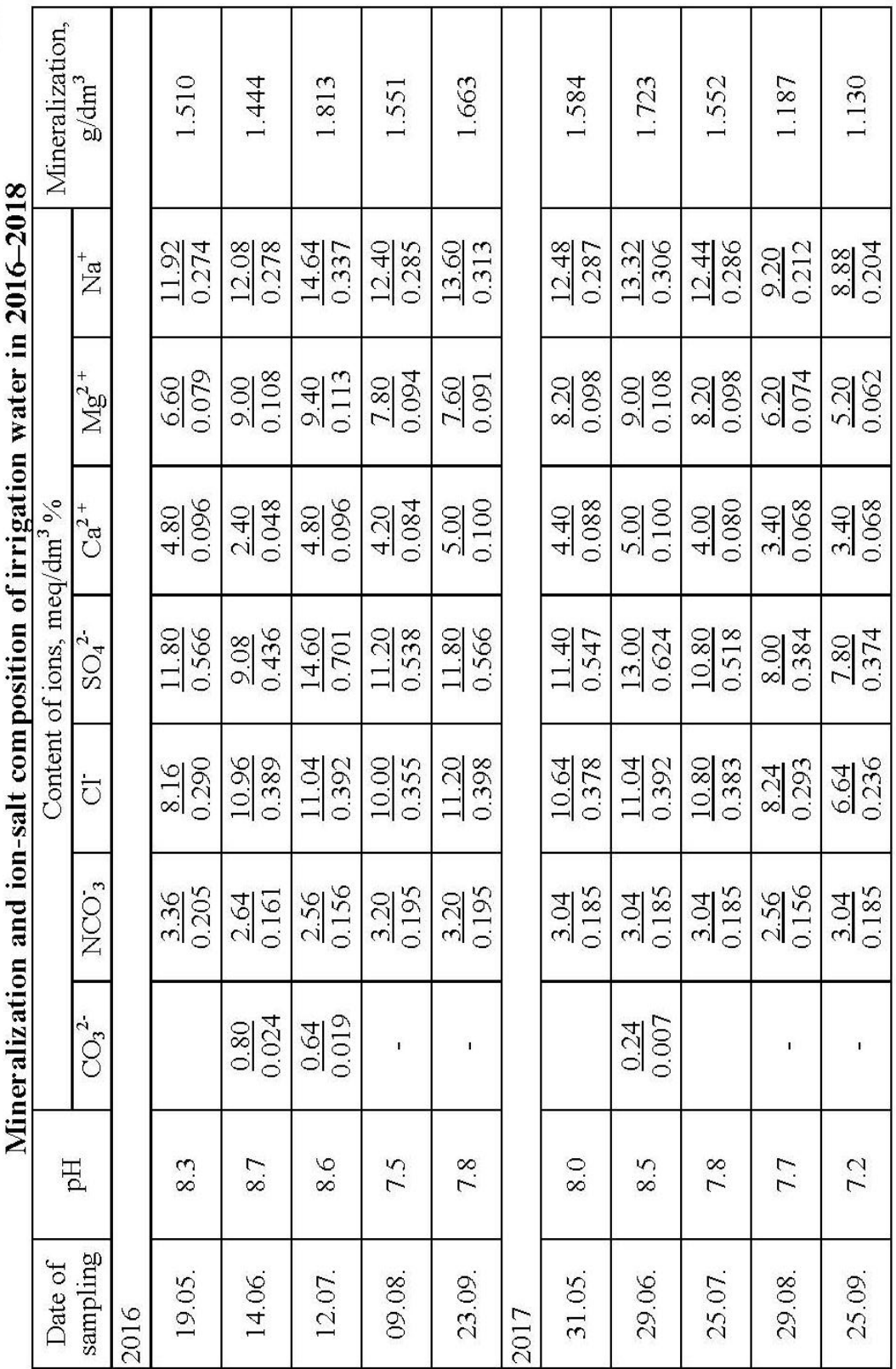




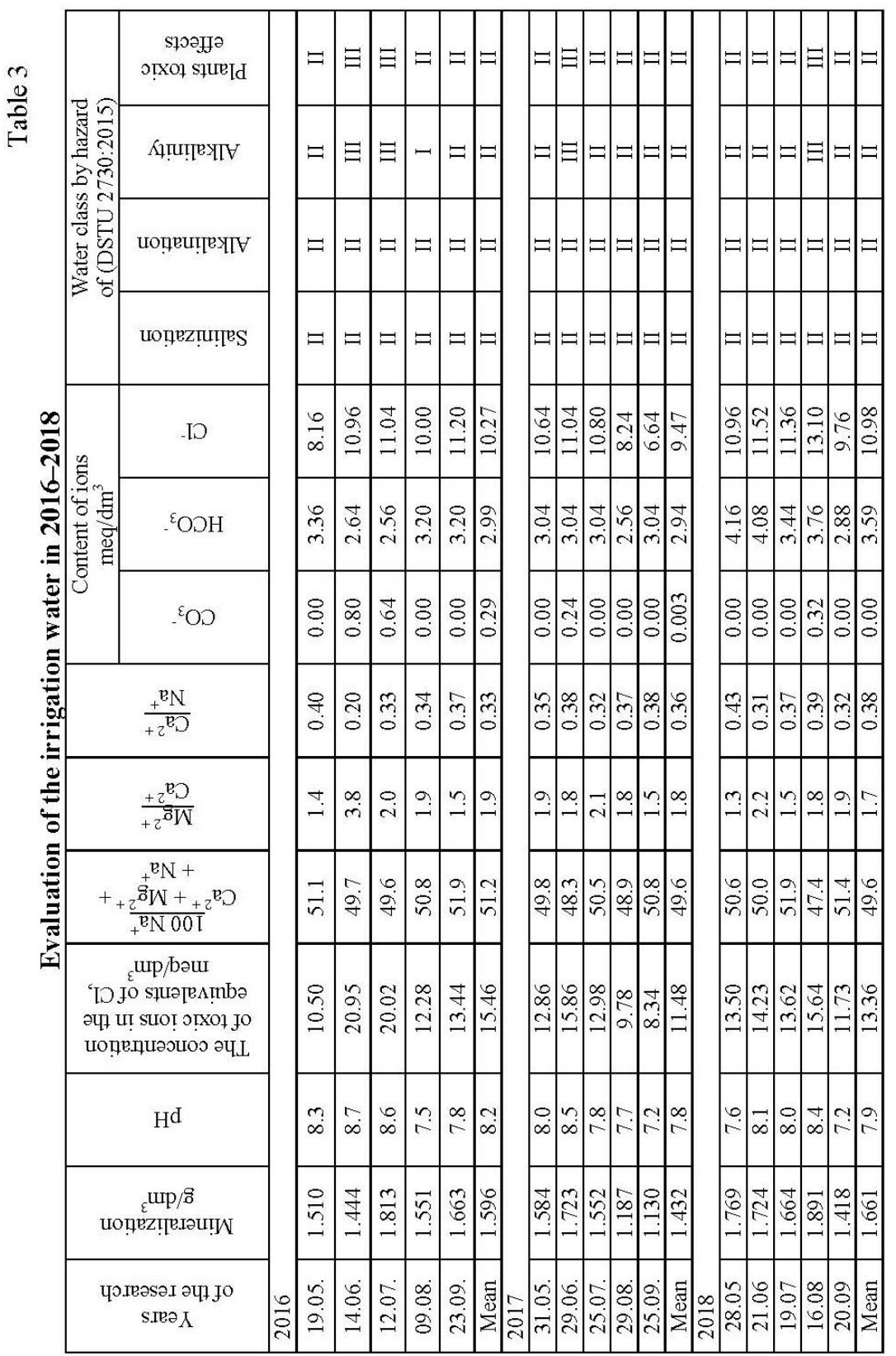


By the hazard of soil alkalinity increase, salinization and toxic effects on plants, the irrigation water also belongs to the same class of quality. The value of water $\mathrm{pH}$ changed within 7.2 to 8.7. In certain summer periods of water sampling, the water in the pool by the presence of $\mathrm{CO}_{3}^{-}$and high $\mathrm{pH}$ of 8.5 belonged to the III class by the alkalinity hazard and its toxic influence on plants.

The ratio of calcium to sodium content is an important criterion of irrigation water assessment. In the irrigation water, used in our experiments, this ratio was 0.36 , indicating the activity of sodium cations.

Thus, according to the acting standard, the irrigation water belongs to the class II and it is limited suitable for irrigation by the threat of secondary salinization, alkalination, alkalinity increase and toxic effects on plants.

\section{Dynamics of exchangeable cations and ion-salt composition of water extraction of the soil}

Analyzing materials on the content of exchangeable cations in the $0-40 \mathrm{~cm}$ layer of the soil at the end of the vegetation, it is possible to conclude that the least process of alkalination occurs under plowing in the system of long-term application of the different-depth soil tillage and in the system of differentiated tillage in the crop rotation (variants 1 and 4) (Table 4).

The share of exchangeable sodium in the soil layer $0-40 \mathrm{~cm}$ increased in the soil absorption complex at the expense of the absorbed calcium, the content of which relatively decreased (variant 1) at the plowless ways of tillage by $2.67-3.48 \%$, and at the plowing at the depth of $18-20 \mathrm{~cm}$ in the system of differentiated soil tillage in the crop rotation (variant 5) - by $2.97 \%$. Under the disk tillage at the depth of $8-10 \mathrm{~cm}$ in the system of differentiated tillage of the crop rotation (variant 4), the content of $\mathrm{Ca}^{2+}$ was at the level of the plowing (variant 1) and fluctuated within $66.2-68.3 \%$ from the sum of the cations. Application of fertilizers with the doses $\mathrm{N}_{120}$ and $\mathrm{N}_{180}$ increased the $\mathrm{Ca}^{2+}$ content by $1.7-2.1 \%$ of the sum of the cations. The conduction of plowing in the system of prolonged application of different-depth moldboard soil tillage (variant 1) and the system of differentiated tillage in the crop rotation (variant 4) positively affected the amount of exchangeable cations in the soil, which was the largest and fluctuated 
in the layer 0-40 cm within 20.9-21.0 meq/100 g, in the variants with application of fertilizers there is also a tendency to the increase by $0.3-0.4 \mathrm{meq} / 100 \mathrm{~g}$ of soil.

Table 4

Dynamics of exchangeable cations in the dark-chestnut soil at different methods of basic tillage and doses of fertilizers at the end of vegetation (the average for 2016-2018)

\begin{tabular}{|c|c|c|c|c|c|c|c|}
\hline \multirow[t]{2}{*}{ Variant } & \multicolumn{3}{|c|}{$\begin{array}{c}\text { Content of } \\
\text { exchangeable } \\
\text { cations, } \\
\text { meq } / 100 \mathrm{~g} \text { of soil }\end{array}$} & \multirow[t]{2}{*}{$\begin{array}{l}\text { Number of } \\
\text { exchangeable } \\
\text { cations, } \\
\text { meq/100 g } \\
\text { of soil }\end{array}$} & \multicolumn{3}{|c|}{$\begin{array}{l}\text { Share of the } \\
\text { cation, } \%\end{array}$} \\
\hline & $\mathrm{Ca}^{2+}$ & $\mathrm{Mg}^{2+}$ & $\mathrm{Na}^{+}$ & & $\mathrm{Ca}^{2+}$ & $\mathrm{Mg}^{2+}$ & $\mathrm{Na}^{+}$ \\
\hline \multicolumn{8}{|c|}{ Without fertilizers } \\
\hline Plowing & 13.8 & 6.4 & 0.78 & 21.0 & 65.8 & 30.5 & 3.7 \\
\hline Plowless-1 & 13.2 & 6.6 & 0.80 & 20.6 & 64.1 & 32.0 & 3.9 \\
\hline Plowless-2 & 13.0 & 6.8 & 0.82 & 20.6 & 63.0 & 33.0 & 4.0 \\
\hline Differentiated-1 & 13.8 & 6.3 & 0.75 & 20.9 & 66.2 & 30.2 & 3.6 \\
\hline Differentiated-2 & 13.4 & 6.6 & 0.80 & 20.8 & 64.4 & 31.7 & 3.8 \\
\hline \multicolumn{8}{|c|}{$\mathrm{N}_{120}$} \\
\hline Plowing & 14.4 & 6.2 & 0.71 & 21.3 & 67.6 & 29.1 & 3.3 \\
\hline Plowless-1 & 13.7 & 6.4 & 0.76 & 20.9 & 65.7 & 30.7 & 3.6 \\
\hline Plowless-2 & 13.3 & 6.7 & 0.79 & 20.8 & 64.0 & 32.2 & 3.8 \\
\hline Differentiated-1 & 14.4 & 6.1 & 0.72 & 21.2 & 67.9 & 28.7 & 3.4 \\
\hline Differentiated-2 & 13.8 & 6.4 & 0.75 & 21.0 & 65.9 & 30.5 & 3.6 \\
\hline \multicolumn{8}{|c|}{$\mathrm{N}_{180}$} \\
\hline Plowing & 14.6 & 6.1 & 0.66 & 21.4 & 68.4 & 28.6 & 3.1 \\
\hline Plowless-1 & 14.3 & 6.3 & 0.74 & 21.3 & 67.0 & 29.5 & 3.5 \\
\hline Plowless-2 & 13.4 & 6.4 & 0.77 & 20.6 & 65.1 & 31.1 & 3.7 \\
\hline Differentiated-1 & 14.5 & 6.1 & 0.64 & 21.2 & 68.3 & 28.7 & 3.0 \\
\hline Differentiated-2 & 14.1 & 6.2 & 0.73 & 21.0 & 67.0 & 29.5 & 3.5 \\
\hline
\end{tabular}

$\mathrm{LSD}_{05}, \mathrm{meq} / 100 \mathrm{~g}$ soil:

$$
\begin{aligned}
& \mathrm{A}=0.02, \mathrm{~A}=0.18 \mathrm{~A}=0.005 \\
& \mathrm{~B}=0.03, \mathrm{~B}=0.02 \mathrm{~B}=0.006
\end{aligned}
$$

On the variants with the system of prolonged use of differentdepth plowing soil tillage in the crop rotation (variant 1) and in the system of differentiated tillage in the crop rotation (variant 4) and 
fertilizers application there was a tendency to the decrease of salinization by slightly mineralized irrigation water, where the highest content of absorbed calcium was fixed in the share of the cations of $67.6-68.4 \%$. Whereas the content of magnesium and sodium was the largest under shallow plowless tillage (variant 3) -33.0 and $4.0 \%$ without fertilizer, and 31.1-32.2 and 3.7-3.8\% of the cation sum under fertilizers application that testifies about a slight increase in the secondary salinity in the variants with plowless way of tillage without fertilizers application.

Thus, irrigation with the water of high mineralization having adverse ratios of single-and divalent cations leads to changes in the qualitative composition of SAC at the end of crops vegetation that is accompanied by the increase of the share of exchangeable sodium and contributes to the development of the process of irrigative soil salinization.

The studies showed that irrigation with the Ingulets water with adverse ratio of mono- and bivalent cations leads to the changes in ionsalt composition of the soil water extraction. Thus, at the end of the vegetation, the content of water-soluble salts in the layer $0-40 \mathrm{~cm}$ increased in all the variants to $0.101-0.152 \%$. The increase in the salts content mainly occurred at the expense of the increase of $\mathrm{SO}_{4}{ }^{2-}$ and $\mathrm{Cl}^{-}$ ions among the anions and $\mathrm{Na}^{+}$among the cations. The content of toxic salts also increased in all the variants of the experiment in $0-10 \mathrm{~cm}$ layer by $0.45-0.9$ times and in the $0-40 \mathrm{~cm}$ layer by $0.38-0.87$ times.

However, the least their content is noted in the system of differentiated tillage in the crop rotation (variant 4) on the background of $\mathrm{N}_{180-} 0.064$ in the layer $0-10 \mathrm{~cm}$ and $0.065 \%$ in the layer $0-40 \mathrm{~cm}$. The ratio of calcium to sodium cations in the soil solution varies in the layer $0-10 \mathrm{~cm}$ in the range of 0.38 to 0.61 units, and in the $0-40 \mathrm{~cm}$ from 0.39 to 0.61 units points to the development of the active process of secondary alkalination (Table 5).

The transformation of the ionic composition of the water extraction led to the change in the chemistry of salinization, it became chloride-sulphate calcium-sodium in all the variants, regardless of the studied factors. Exchangeable processes in the soil-absorption complex have caused the increase of quantity of sodium cations in the soil solution. 


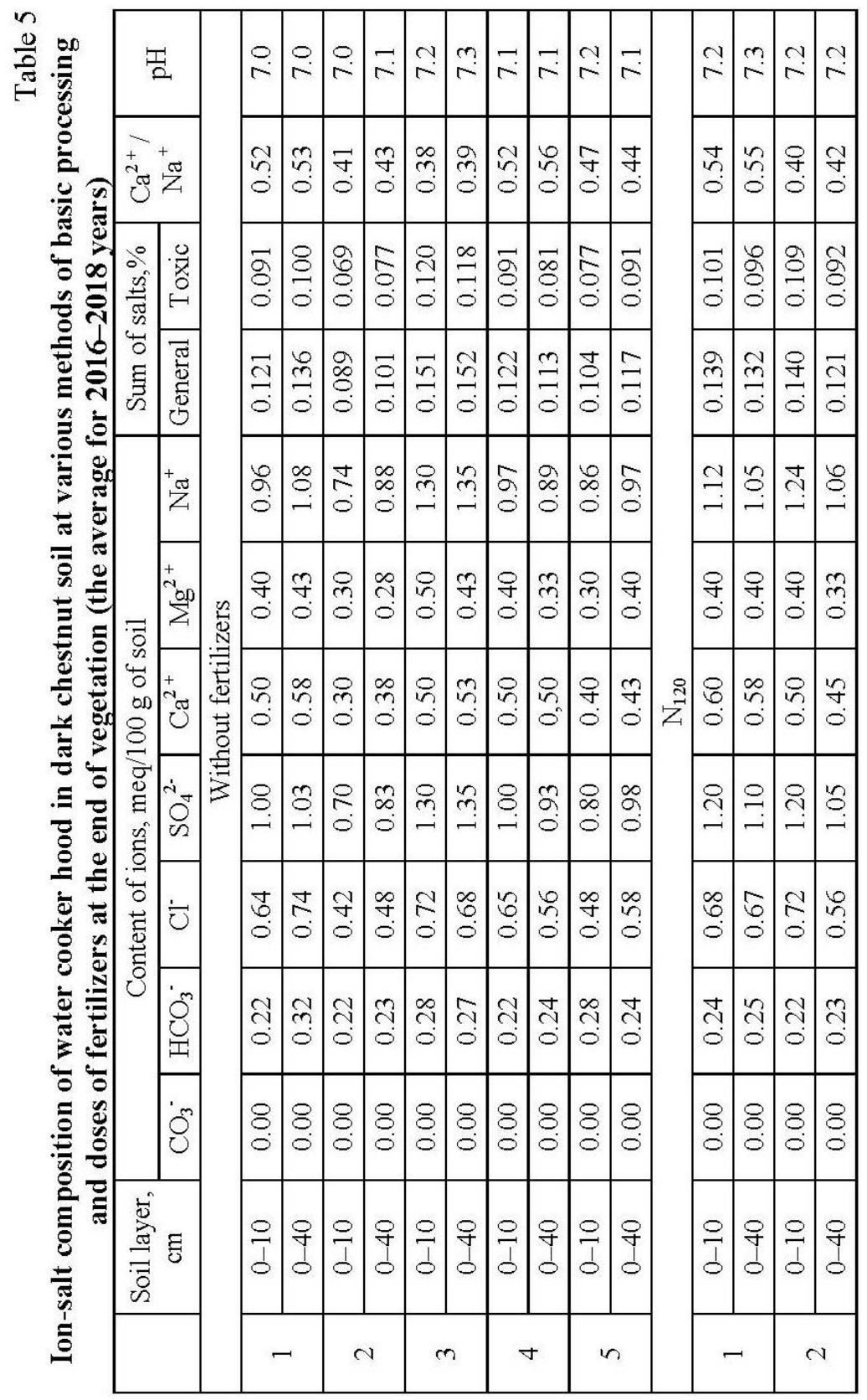


The largest their content in the layer $0-40 \mathrm{~cm}$ of $1.26-1.35 \mathrm{meq} / 100 \mathrm{~g}$ of soil was observed on the variants of disk tillage at the depth of 12-14 cm in the system of shallow single-depth plowless soil tillage in the crop rotation (variant 3 ). Also, under this tillage option, the largest amount of sodium is fixed with no fertilizers applied in the experiment 1.30 in the layer $0-10 \mathrm{~cm}$ and $1.35 \mathrm{meq} / 100 \mathrm{~g}$ in the layer $0-40 \mathrm{~cm}$.

The analysis of yield data in the crop rotation on average for 2016-2018 showed that in comparison to the plowing at the depth of $20-22 \mathrm{~cm}$ in the system of prolonged use of different-depth plowing soil tillage in the crop rotation (variant 1) the increase of corn yield was only under the carrying out tillage at the depth of $8-10 \mathrm{~cm}$ in the differentiated tillage system (variant 4) and constituted on average by the factor A (soil tillage method) 2.8\%, with the level of yield depending on the dose of fertilizers 11.09-14.59 t/ha (Table 6).

Carrying out the disk tillage at the depth of $12-14 \mathrm{~cm}$ in the system of shallow single-depth plowless tillage in the crop rotation (variant 3 ) resulted in the decrease in the yield by $26.2 \%$, and without fertilizer application it was up to the least yiled in the experiment of $3.06 \mathrm{t} / \mathrm{ha}$. Fertilizer application of $\mathrm{N}_{120}$ and $\mathrm{N}_{180}$ increased the yield on average by the factor B (fertilizer dose) by 185.1 and 270.5\%, respectively. Application of $\mathrm{N}_{90}$ under sorghum resulted in the yield increase by $173.7 \%$, increasing the dosage of mineral fertilizers contributed to a lesser increase in the yield in comparison to other crops in the experiment, which on the background of $\mathrm{N}_{120}$ averaged to $179.2 \%$. At the impact of soil tillage on sorghum yield the same tendency as on other crops is observed.

Chisel tillage at the depth of $12-14 \mathrm{~cm}$ with slotting at the depth of $38-40 \mathrm{~cm}$ in the system of differentiated soil tillage (variant 4) in comparison to plowing at the depth of $23-25 \mathrm{~cm}$ in the system of prolonged use of the differentiated plowing soil tillage in the crop rotation (variant 1) resulted in the yield increase on average by factor A ("soil tillage method") by $14.2 \%$. 


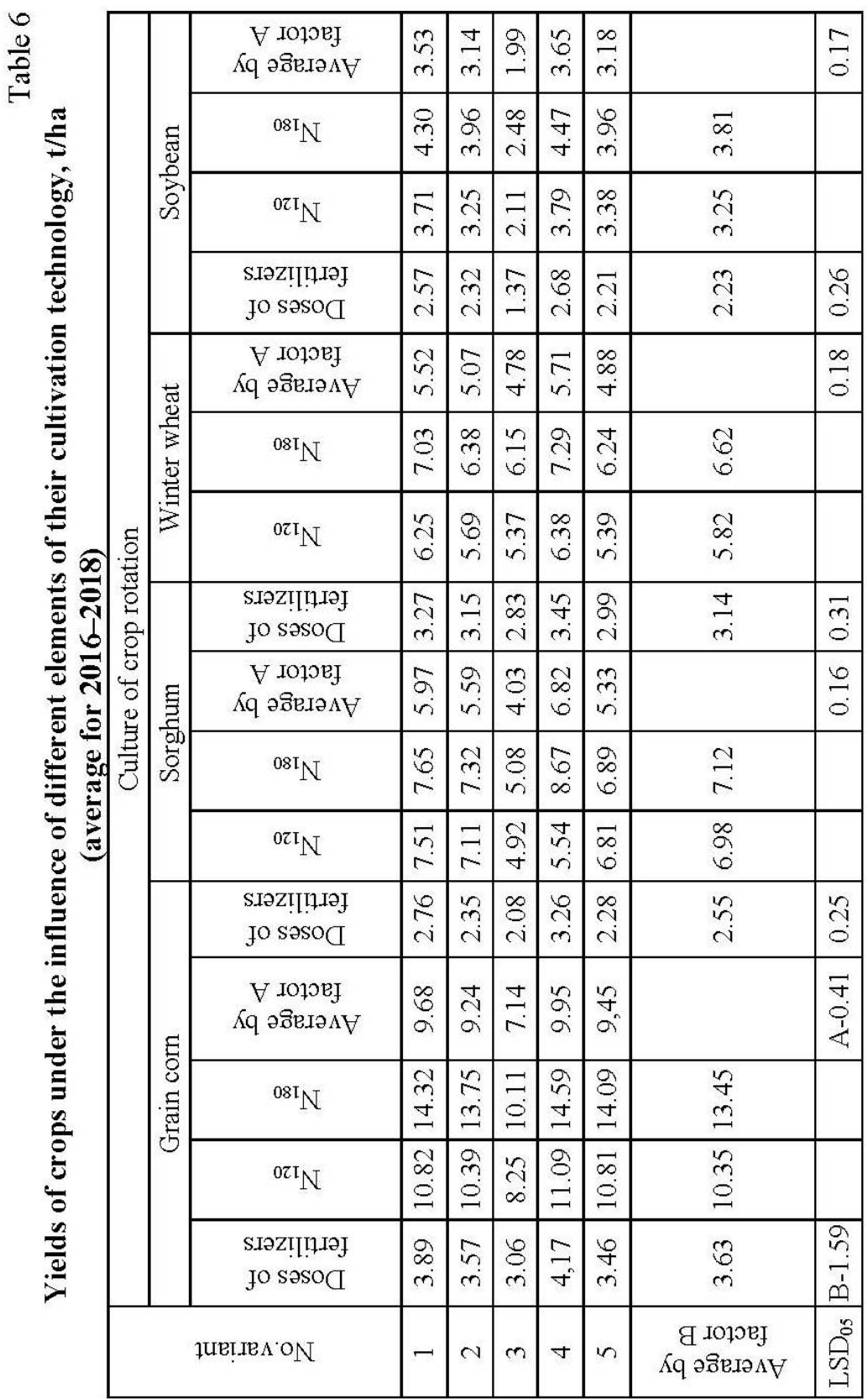


Replacement of deep tillage with disk tillage at the depth of $12-14 \mathrm{~cm}$ in the system of prolonged use of single-depth shallow plowless soil tillage in the crop rotation (variant 3) resulted in a decrease in yield by $32.5 \%$, at the other variants by $6.4-10.7 \%$. The highest yield in the experiment was obtained under the conduction (variant 4) and application of mineral fertilizers in the dose of $\mathrm{N}_{120}$, which averaged to $8.67 \mathrm{t} / \mathrm{ha}$. In the experiment with winter wheat, fertilization increased the yield of the crops on average by factor B ("fertilizer dose") by 85.4 and $110.8 \%$, respectively. The impact of the methods of soil tillage on the yield of winter wheat was less. The disk tillage at the depth of $8-10 \mathrm{~cm}$ in the system of differentiated soil tillage with one slotting per the crop rotation (variant 4) resulted in the increase of winter wheat yield on average by factor A ("soil tillage method") by $3.4 \%$, whereas at the other variants $(2,3,5)$ the yield losses compared with the plowing at the depth of $14-16 \mathrm{~cm}$ in the system of prolonged use of different-depth plowing soil tillage in the crop rotation (variant 1) was from 8.2 to $13.4 \%$.

The level of soybean yield at plowing at the depth of $25-27 \mathrm{~cm}$ (variant 1) and disk tillage at the depth of 14-16 cm (variant 4) on the fertilized backgrounds was the best and constituted, depending on the doses of fertilizers, 3.53-4.30 t/ha and 3.65-4.47 t/ha, respectively. Under the reduction of tillage depth (variant 3 ) the yield decreased on average by factor A ("soil tillage method") by $43.6 \%$, compared to the control, and under the application of $\mathrm{N}_{30} \mathrm{P}_{60}$ and $\mathrm{N}_{60} \mathrm{P}_{60}$ - increased on average by factor B ("fertilizer dose") by 45.7 and $70.9 \%$, respectively.

By the results of statistical evaluation, there is a strong positive correlation relationship $(r=0.8227)$ between the soybean productivity and the ratio of $\mathrm{Ca}^{2}+\mathrm{Na}^{+}$in the water extraction of the soil. A correlation-regression analysis of the experimental data allowed finding out the dependence of soybean yield on the ratio of $\mathrm{Ca}^{2+} / \mathrm{Na}^{+}$. The calculations proved that under the increase of the ratio of $\mathrm{Ca}^{2+} / \mathrm{Na}^{+}$ in the water extraction of the soil higher level of soybean yield was formed. The discovered dependencies allowed us to suggest that changes in the formation of soybean productivity by $80 \%$ could be caused by the changes in the ratio of $\mathrm{Ca}^{2+} / \mathrm{Na}^{+}$in the water extraction of the soil, i.e. from agrophysical and chemical properties of the soil.

Thus, the best conditions for the formation of yields in the experiment were created by the differentiated soil tillage system with 
one slotting per the crop rotation (variant 4), and the application of the increased doses of fertilizers.

Evaluating the economic efficiency of agricultural methods of the crops cultivation, the expenditures were calculated according to the norms and prices, which were actual in the production boundaries of the Steppe zone of Ukraine in 2018.

The highest profit from 1 ha of the crop rotation area $(35,223 \mathrm{UAH} / \mathrm{ha})$ was obtained at the nutrition background $\mathrm{N}_{120} \mathrm{P}_{60}$ with the differentiated soil tillage (variant 4) (Table 7).

The highest level of profitability $-197 \%$ was determined in the same variant. By the other systems of soil tillage and doses of fertilizers, it decreased to the boundary values of $12-179 \%$. The lowest level of profitability was observed at carrying out disk tillage in the shallow single-depth plowless soil tillage (option 3) on the unfertilized background $-12 \%$. Based on the data analysis, it is possible to say that for 1 ha of the crop rotation area, a chisel tillage at the depth of $12-14 \mathrm{~cm}$ with one slotting at $38-40 \mathrm{~cm}$ per the crop rotation in the system of differentiated soil tillage (variant 4) is the most economically advantageous. Also, the energy evaluation of such elements as the system of basic soil tillage, the system of fertilizers application in the crop rotation was carried out. The outlet of gross energy for 1 ha of the crop rotation area depending on the methods of basic soil tillage and doses of fertilizers was the highest in the unfertilized variant and at the nutrition background of $\mathrm{N}_{82.5} \mathrm{P}_{60}$ at the chisel tillage at the depth of $12-14 \mathrm{~cm}$ and one slotting at the depth of $38-40 \mathrm{~cm}$ in the system of differentiated tillage (variant 4) and averaged to 65.6 and $143.4 \mathrm{GJ} / \mathrm{ha}$, and at the $\mathrm{N}_{120} \mathrm{P}_{60}$ it was the highest under the prolonged use of different-depth plowing tillage (variant 1) $160.4 \mathrm{GJ} / \mathrm{ha}$, where the indexes of gross energy in the system of differentiated soil tillage (variant 4) were a little bit lower 156.0 GJ/ha.

In the variants with the use of the different-depth plowless tillage (variant 2) and the differentiated-2 (variant 5) basic tillage it fluctuated within 127.1-127.2 and 150.3-150.7 GJ per hectare according to nutrition backgrounds. In the variant with the plowless shallow tillage, the gross energy outlet in the variants of fertilization (without fertilizers, $\mathrm{N}_{82.5} \mathrm{P}_{60}$ and $\mathrm{N}_{120} \mathrm{P}_{60}$ ) - decreased to 45.0 GJ, 99.2 and 114.0 GJ, respectively. 


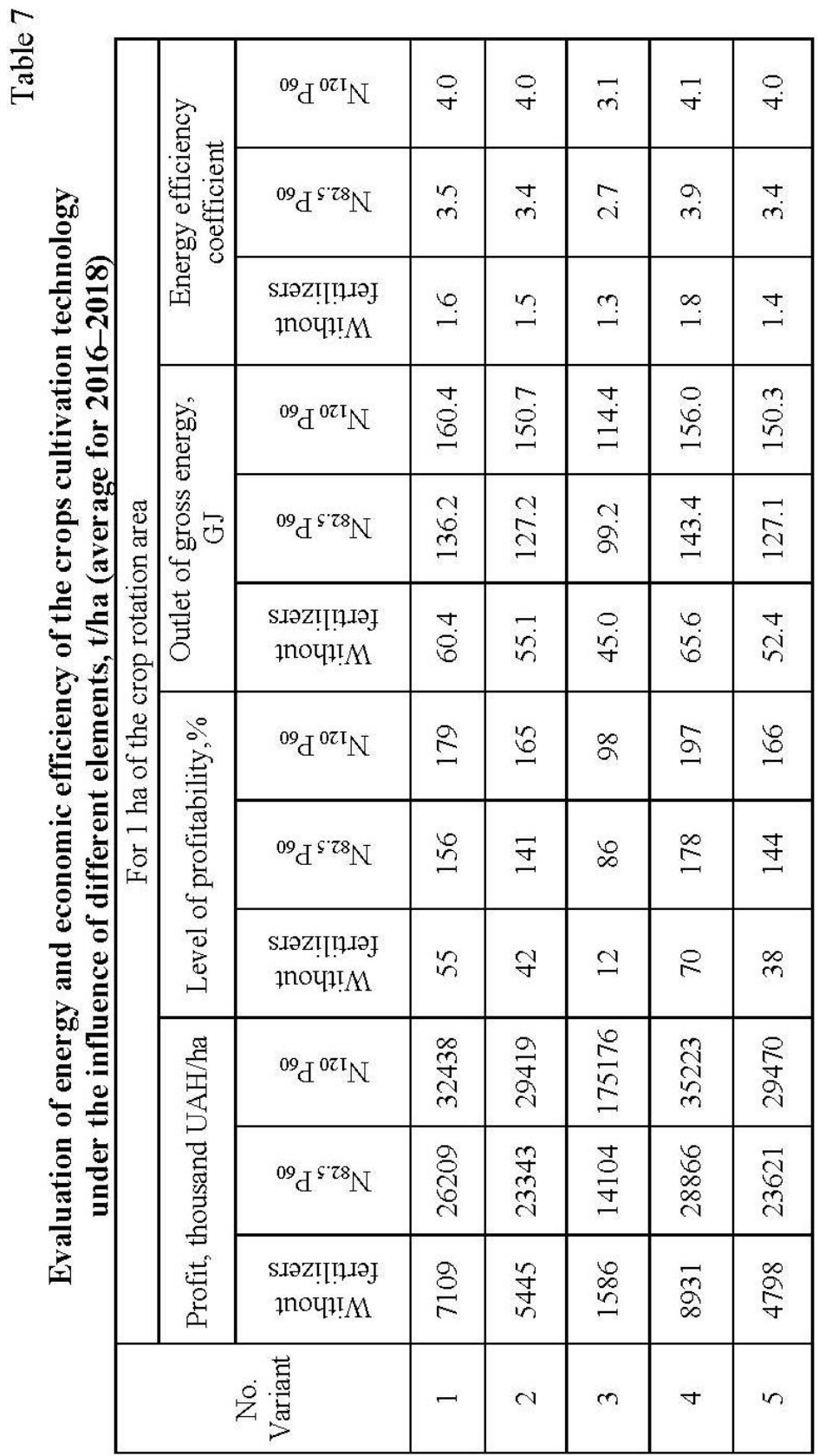


Comparing the energy coefficient (the correlation between energy in the obtained yield and the energy expenditures in the technological cycle of the crop cultivation), it is possible to conclude that the least payback of the costs for the cultivation technology by the fertilizer doses were created at the shallow single-depth basic soil tillage (variant 3), the energy coefficient was 1.3, 2.7 and 3.1 by the nutrition backgrounds of without fertilizers, $\mathrm{N}_{82.5} \mathrm{P}_{60}$ and $\mathrm{N}_{120} \mathrm{P}_{60}$, respectively. While under the chisel tillage at the depth of $12-14 \mathrm{~cm}$ with one slotting at $38-40 \mathrm{~cm}$ per the crop rotation in the system of differentiated soil tillage (variant 4) it gained the maximum value and reached 1.8, 2.9 and 4.1 by the nutrition backgrounds, respectively.

\section{CONCLUSIONS}

By the results of the study we have determined that according to the actual standard the irrigation water of the Ingulets irrigation system belongs to the Class II and is limited suitable for irrigation by the threat of secondary salinization, alkalination, alkalinity increase and toxic effects on plants. Irrigation with the waters of high mineralization with adverse ratios of single-and divalent cations leads to the changes in the qualitative composition of the SAC at the end of the vegetation of crops, where leaching calcium out of the soil is observed, which is accompanied by the growth of the share of exchangeable sodium and contributes to the development of the process of irrigative alkalination of the soil.

Conduction of different methods of basic soil tillage and application of different doses of fertilizers cannot eliminate the process of irrigative alkalination, and at the plowing and differentiated tillage, where plowing during the crop rotation alternates with shallow plowless loosening under the crops of the rotation, with the use of nitrogen fertilizers, where the largest content of absorbed calcium from the sum of cations of $67.6-68.4 \%$ was noted, its slight decline was fixed, which allowed obtaining on average for three years for the hectare of the crop rotation area the highest yield.

\section{SUMMARY}

The goal is to determine the changes in physical and chemical properties of irrigated soil at different melioration loads. By the results of the research, it was established that with accordance to the actual 
standard the irrigation water of the Ingulets irrigation system belongs to the Class II and is limited suitable for irrigation by the threat of secondary salinization, alkalination, alkalinity increase and toxic effects on plants. Irrigation with the waters of high mineralization with adverse ratios of single-and divalent cations leads to the changes in the qualitative composition of the SAC at the end of the crops vegetation, where there is leaching of calcium out of the soil that was accompanied by the growth of the share of exchangeable sodium and contributes to the development of the process of irrigative alkalination of the soil. Conduction of different methods of basic soil tillage and application of different doses of fertilizers cannot eliminate the process of irrigative alkalination, and at the plowing and differentiated tillage, where plowing during the crop rotation alternates with shallow plowless loosening under the crops of the rotation, with the use of nitrogen fertilizers, where the largest content of absorbed calcium from the sum of cations of $67.6-68.4 \%$ was noted, its slight decline was fixed, which allowed obtaining for the hectare of the crop rotation area $14.51 \mathrm{t} / \mathrm{ha}$ of corn, 8.58 of sorghum, 7.11 of winter wheat, and $4.49 \mathrm{t} / \mathrm{ha}$ of soybean.

\section{REFERENCES}

1. Ромащенко M. І., Балюк С. А. Зрошення земель в Україні. Стан та шляхи поліпшення. Київ: Світ, 2000. 114 с.

2. Балюк С. А., Ромащенко М. І., Старшук В. А. Комплекс протидеградаційних заходів на зрошуваних землях України. Київ: Аграрна наука, 2013. 160 с.

3. Вожегова Р. А. та ін. Землі Інгулецької зрошувальної системи: стан та ефективне використання. Київ: Аграр. наука, 2010. 352 c.

4. Зубець М. В. та ін. Наукові основи агропромислового виробництва в зоні Степу України. К.: Аграрна наука, 2010. 986 с.

5. Коваленко П. І. та ін. Землеробство в умовах недостатнього зволоження. Київ: Аграрна наука, 2000. 80 с.

6. Малярчук М. П., Марковська О. С., Лопата Н. П. Продуктивність кукурудзи за різних способів основного обробітку грунту та доз внесення добрив в сівозміні на зрошенні півдня України. Зрошуване землеробство: міжвідом. темат. наук. зб. 2017. Вип. 67. C. $47-51$. 
7. Сайко В. Ф., Малієнко А. М. Системи обробітку грунту в Україні. Київ: ЕКМО, 2007. 44 с.

8. Вожегової Р. А. та ін. Методика польових і лабораторних досліджень на зрошуваних землях: навч. посіб. Херсон: Грінь Д.С., 2014. $286 \mathrm{c.}$

9. Захист довкілля. Якість природної води для зрошення. Агрономічні критерії: ДСТУ 2730:2015. К.: Держстандарт України, 2015. 13 с. (Національний стандарт України).

\section{Information about the author: \\ Bidnyna I. O.,}

Candidate (Ph.D.) of Agricultural Sciences,

Senior Research, Academic Secretary, Institute of Irrigated Agriculture of the National Academy of Agrarian Sciences

Kherson, Naddniprianske, 73483, Ukraine 